\title{
ADAPTATION OF CONVICTS' LEGAL STATUS TO EUROPEAN STANDARDS
}

\section{Batiuk O. V.}

\section{INTRODUCTION}

In 2004 already Ukraine adopted Law "On national programme of adapting legislation of Ukraine to European Union legislation”, in 2014 "On introducing changes to Criminal executive code of Ukraine concerning adaptation of convicts' legal status to European standards", which laid the foundations of modifying criminal executive legislation taking European law requirements and norms into consideration, including the problems of applying physical force, special means and weapon to imprisoned convicts (international law norms call it suppressing convicts measures).

Adopting the Conception of reforming (developing) penitentiary system of Ukraine in September 2017 also became an important step in this direction, as the activity of realizing the content of penitentiary policy instead of present criminal executive policy in the sphere of punishment execution was defined to be one of its priorities.

A one of the tasks of modern reform of bodies and punishment execution institutions, which are enshrined in the Concept of the reform (the development) of the penitentiary system of Ukraine in September 2017, determined development of legislation in the field of functioning of the IIW and the PEI in accordance with legislation of the EU.

Accordingly, the putting the question regarding the international legal approaches and the practice of the application to convicts that are deprived of liberty, of the restraint measures is obvious and such that has theoretical and applied importance.

\section{International legal acts and the practice of their realization}

Thus, according to the art. 1 of the Statute of the Council of Europe, the EC objective is also achieved through the conclusion of agreements and the application of joint measures in the legal field ${ }^{1}$.

In addition, scientists point to the existence of several modern processes that affect the legislative provision of the field of crime the combating, the organic constituent element of which is the criminal executive activity, namely: a) the globalization of world relations, which also entails negative consequences; b) the significant expansion of the EU recently

Статут Ради Європи від 5 травня 1949 р. Офіиійний вісник Украӥни. 2004. № 26. Ст. 17. 
(the accession to the European Union of the Montenegro, the Croatia, etc.); c) the perception of the Ukraine at the level of the state of legislative work of the EU; d) the integration of Ukraine, including on the issues of the execution - serving sentences to the EU.

In the context of the explored problematic in this work, another fact that contributes the necessary the pursuit of the communist (the comparativelegal) scientific searches in the field of the execution of sentences is that despite the worldwide recognition and the distribution in Ukraine as well as in foreign countries, of sentences, which are not related to the deprivation of liberty, and of the system of probation, according to the international official data, the number of convicts in the last 15 years in the world has increased by $25-30 \%$, and the coefficient of the convicts to the deprivation of liberty in the world is 144 per 100 thousand persons.

If you summarize all the scientific approaches that are involved in clarifying the content of the international legal acts in the field of the serving sentences, then it should be noted that most of them lead to the international standards of a general nature. These include:

- the general Declaration of the human rights;

- the Declaration of the rights of the child;

- the International covenant on the economic, the social and the cultural rights; the other.

In addition, the subject of research on the specified problematic are also the international legal sources of the special direction, namely:

a) the minimum standard rules for the treatment of the convicts;

b) the European penitentiary rules;

c) the set of principles for the protection of all persons who are detained or imprisoned in any way;

d) the other international legal acts concerning the sphere of the execution of sentences.

In doing so, the scientists have come to the conclusion that international legal acts on the legal technique of their execution was inherent in, so to speak, "the description", whereas for the national legal sources was more inherent in "the normativity".

Moreover, in studies of the provisions of the different international acts and standards, it is generally accepted that the term "the prison" is used to refer to any place of the isolation of a person (with the exception of the special treatment institutions), and "the imprisoned" - to identify both the convicts and persons that are arrested or placed in a special institution without the pressing charges. 
In addition, based on the results of the current research, the international legal acts on the issues of the application to the convicts in the places of their isolation (and namely, in this sense are used in this work such terms, that are enshrined in the specified sources and relate to the characteristic of these individuals) of the restraint measures that are classified (it is based on the criterion of the legal regulation of the specified issues) into:

1) the international legal acts of the general nature, that is, those which are set out the general principles and approaches that are related to the legal restrictions, which are imposed on the convicts (The General Declaration of the human rights, etc.);

2) the international legal sources of the specialized content, that is, those that directly regulate the issues of the execution - the serving sentences and the treatment with the convicts;

- the minimum standard rules for the treatment with convicts;

- the EPR;

- the convention against the torture and other cruel, inhuman or degrading types of the treatment and punishment;

- the Minimum standard rules of the UN regarding the execution of the justice regarding juvenile;

- the other acts of the special content;

3) the international legal acts that directly relate to issues that are related to the application the restraint measures to convicts:

- the code of the conduct for the law enforcement officials in maintaining law and order;

- the principles of the medical ethics;

- the set of principles for the protection of all persons who are detained or imprisoned in any way;

- the other acts that are directly related to the problematic that is explored in this work.

Such approach not only made it possible to compare the content of similar regulatory sources of national and international law, but also to develop a number of scientifically sound proposals, which are aimed at improving the legal basis and order of the application in Ukraine of the measures of physical influence, special means and weapon to convicts that deprived of liberty.

In particular, such a general international legal act as the General Declaration of human rights states the following:

1. Every human has the right to life, liberty and personal safety (the article 3 of the Declaration). 
In turn, in the art. 3 of the Constitution of Ukraine this provision has been expanded and has the following content: the human, his life and health, the honor and the dignity, the safety and the security are determined in Ukraine by the highest social value ${ }^{2}$.

Moreover, the art. 27 of the Basic law states that everyone has an inalienable right to the life, the art. 28 - the provision about that no one can be tortured, inhuman or degrading treated or punished, and in the art. 29- the requirement that every human has the right to liberty and the personal safety.

\section{The right of convicts for the personal safety}

The art. 10 "The right of convicts for the personal safety" of the CEC the procedure of actions of the administration of the PEI in case of the inception of danger to the life and health of convicts that are serving sentences in the way of deprivation of liberty was determined.

At the same time, neither in the specified norms of this Code, nor in its entirety in the chapter "The Legal status", is not maintained that the restraint measures, which are applied to convicts that are deprived of liberty, also refer to measures of the provision the right of these persons for personal safety.

Given the specified and the provisions of the art. 3 of the Declaration, the art. 10 of the Criminal executive code of Ukraine (CEC) should be supplemented with the part 6 with the following content:

"In the defined by law cases of the provision the right of convicts for the personal safety is applied by the way of the application of the measures of physical influence, special means and weapon to offenders".

Such an approach would organically combine the norms of the General and Special part of the CEC, that are governing the above issues and would realize at the normative level the principle of systematic construction of legal norms, even in cases of their codification.

Moreover, in the currentcase, the proposed changes to the art. 10 of the CEC fully reflect the content of the part 1 of the art. 106 of this Code, according to which the measures of physical influence, special means and weapon to the convicts that are deprived of liberty to prevent harming the environment by these persons.

2. Nobody must not be subjected to torture or to cruel, inhuman or degrading treatment and punishment (the art. 5 of the Declaration) ${ }^{3}$.

\footnotetext{
2 Конституція України. Київ : Алерта, 2019. 81 с.

3 Загальна декларація прав людини. Збірник міжнародно-правових актів та угод з питань діяльності пенітенціарних установ $i$ поводження з в'язнями. Київ: Вид-во «AHHA-T», 2008. C. 13-17.
} 
A similar provision was reflected in the art. 28 of the Constitution of Ukraine, the Convention against torture and another cruel, inhuman or degrading treatment and punishment, which has been ratified by Ukraine and which, in accordance with the requirements of the art. 9 of "The Basic law", became part of the national legislation of our country, and also - in the part 3 of the art. 50 of the $\mathrm{CrC}$ and in the part 1 of the art. 1 of the Criminal executive code of Ukraine.

However, it should be noted that in the art. 106 of the CEC nothing is noticed in this regard, although the restraint measures that determined by law to convicts prisoners have objectively inherently certain physical, mental and other consequences for their application.

Based on this, and taking into account the provisions of the art. 5 of the Declaration logically would be that the art. 106 of the Code of criminal procedure should be supplemented with the part 7 of the following content:

"The application of measures of physical influence, special means and weapon is not intended to cause the physical suffering or the humiliation human dignity".

As E. Svanidze rightly noticed in this regard, absolute prohibition of torture and inhuman or degrading treatment in all likelihood require the fight against impunity where such a prohibition is violated ${ }^{4}$.

The same conclusion was reached by D. Mardokh, who reasonably believes that the right to freedom from torture and to cruel, inhuman or degrading treatment and punishment is the imperative norm of the international law ${ }^{5}$.

Considering that one of the goals of the criminal executive legislation of Ukraine, which is enshrined in the part 1 of the art 1 of the Criminal executive code, is the prevention of the torture and inhuman or degrading treatment with convicts, the supplement to the art. 106 of this Code with the proposed provision is a reasonable and necessary measure, which, as in the previous cause, is objectively conditioned by the requirements of the General part of the Criminal executive code.

3. In the execution their rights and freedoms, every human should only be subject to such restrictions that are prescribed by law solely for the purpose of the provision of the proper recognition and of the respect, the rights

\footnotetext{
4 Сванидзе Э. Эффективные расследования жестокого обращения. Руководящие принципы по применению европейских стандартов. Киев : Изд-во «ВПК Экспресс-полиграф», 2011. C. 6 .

5 Мардох Д. Боротьба з жорстоким поводженням і безкарністю та ефективне розслідування жорстокого поводження. Доповідь по Україні. Київ : «К.І.С.», 2010. С. 5.
} 
and the freedoms of others and the provision of the just requirements of the morality, the public order and the general well-being in a democratic society (the part 2 of the article 29 of the Declaration).

In the Constitution of Ukraine, the specified provision is reflected in several norms, namely:

a) the article 23 , which states that every human has the right to the free development of his or her personality, without violating the right and the freedom of others, and has the duties to a society that ensures the free and full development of his personality;

b) the part 3 of the art. 63 , in which it is stated that the convict enjoys all the rights of the human and citizen, except for the limitations that are specified by law and established by a verdict of the court;

c) the article 68 , in which the provision that everyone is obliged to strictly abide by the Constitution of Ukraine and the laws of Ukraine, not to infringe on the rights and the freedoms, the honor and the dignity of others is enshrined.

Considering the provisions of the General Declaration of the rights of human and of the Constitution of Ukraine, the part 1 of the art. 106 of the Criminal executive code of Ukraine should be supplemented by the by the sentence with the following content:

"The application of the specified in the law restraint measures is a right of the persons from the number of the personnel of the colonies, even in the causes of the receiving orders from the side of their management regarding the execution of such actions".

With this approach, it seems that not only the number of the applications to convicts that deprived of liberty, of the measures of physical influence, special means and weapon will decrease, but the principle of the rational application of coercive measures and the stimulus of the law-abiding behavior will also be implemented more substantially and effectively on the practice.

As I.S. Mykhalko rightly noticed in this regard, the peculiarity of the current principle is, first of all, in the fact that the subject of its regulation are:

- firstly, the various emergent extreme forms of the deviant behavior of the convicts, the most conflicting, deviating from the norm of relations;

- secondly, the law-abiding behavior that deserves stimulation, where the methods, the measures of the influence, the remedies 
and the re-socialization of the convicts are mainly indicated and united in the content of the principle . $^{6}$

It is for these reasons and in the order of the prevention of unlawful applicationto persons, serving thesentences intheeducational and correctional colonies, of the specified in the law measures of the restraint nature, and so, the realization on the property level such an element of an order of the criminal executive legislation of Ukraine as the prevention of the torture and inhuman or degrading treatment with convicts, and the proposed above modification of the part of the art. 106 of the Criminal executive code of Ukraine.

So, if to summarize the results of comparing the content of the General Declaration of the rights of human and the norms of the criminal executive legislation of Ukraine, which concerns legal grounds of the application to convicts in the places of deprivation of liberty, of the restraint measures (the places of isolation - on the international legislation), then it should be noted that the latter do not conform to the specified general international normative legal act, which necessitated the development, within the framework of the current study, of appropriate science-based measures regarding the improvement, in particular, of the norms of the current Criminal executive code of Ukraine.

As the results of the study of some other common international legal acts on the specified problematic have demonstrated, the similar approaches are enshrined in these sources.

Thus, in the part. 2 of the art. 2 of The International covenant on the civil and political rights it is stated that if it has not been yet provided for by the existing legislative and other measures, each state - the a participant of this Covenant undertakes to take the necessary measures, in accordance with its constitutional procedures and the provisions of this Covenant for the taking such legislative or other measures, which may be necessary for the execution of the rights that are set out in this covenant ${ }^{7}$.

Moreover, in the part 2 of the art. 5 of the current general international law source enshrined that no one restriction or humiliation of any fundamental rights of the human, which are recognized or existing in the any state -

\footnotetext{
6 Михалко I.С. Галузевий принцип раціонального застосування примусових заходів і стимулювання поведінки засуджених як підгрунтя ефективності дії основних засобів виправлення і ресоціалізація засуджених. Засоби виправлення $і$ ресоціалізації засуджених до позбавлення волі : монографія / за заг. ред. Степанюка А.Х. Херсон : Кроссроуд, 2011. C. 285.

7 Міжнародний пакт про громадянські та політичні права: прийнятий 16 грудня 1966 p. Генеральною Асамблеєю ООН (резолюція № 2200 А (КНКНІ). Збірник міжнародноправових актів та угод з питань діяльності пенітенціарних установ і поводження з в'язнями. Київ : Вид-во «АННА-Т», 2008. С. 38.
} 
the participant of this Covenant by the virtue of the law, the conventions, the rules or the customs, it is not permissible on the pretext that such covenants do not define such rights or that they are less defined in such covenants.

In the same context, in the covenant, other rules that are related to the general features of the procedures of the application to convicts in the places of the deprivation of liberty (of the isolation) that are determined in the law, are formulated, namely:

1) In the part 1 of the art. 6 it is determined that the right for the life is an inherent right of every person. This right is protected by the law. No one can be arbitrarily deprived of the life.

In the current criminal executive legislation of Ukraine, despite the fact that a similar norm is in the Constitution of Ukraine (the article 27), there is no specific article on these issues, although its availability, taking into account the specified provisions and content, in particular, of the grounds of the application to convicts that are deprived of liberty, of the measures of physical influence, special means and weapon (the art. 106 of the Criminal executive code of Ukraine), is an obvious.

It is told in this case about that in the Criminal executive code of Ukraine the procedure for application regarding the persons that are deprived of liberty, the weapon as the strictest measure of influence on the person, is not defined. Only partly (in the formal view) in the part 1 and the parts 5, 6 of the article 106 of this Code in the form of remark describes the application of the weapon.

In particular, in the part 5 of the article 106 of the Criminal executive code it is specified that about every cause of the application of the weapon a report is drawn up and the prosecutor and the Commissioner of the Verkhovna Rada for the rights of human are immediately notified.

As established in the course of this study, the procedure for the application of weapon against convicts is defined in the Instruction on the organization of the protection of the criminal executive institutions of the closed type and in the Instruction on the organization of the protection and supervision in the correctional colonies, that is, this issue is governed by the by-laws normative legal acts that contrary to the requirements of the paragraph 14 of the part 1 of the article 92 of the Constitution of Ukraine, according to which this activity should be determined only by the law.

As established in this study, the procedure of the application weapon to convicts that is defined in the Instruction on the organization of the protection of the criminal executive closed-type institutions and in the Instruction on the organization of the protection and supervision in the correctional 
colonies, that is, this issue is governed by by-laws normative legal acts, contrary to the requirements of the paragraph 14 of the part 1 of the art. 92 of the Constitution of Ukraine, according to which this activity should be determined only by law.

In addition, this despite the fact of the application of weapon often convicts receive firearm wounds, and this also leads to their death.

At the same time, there was a special article even in the Criminal executive code of Ukraine in 1970, in which the procedure of the application of weapon to convicts in the places of deprivation of liberty was determined (the art. 82) ${ }^{8}$.

Instead, in the current Criminal executive code, the legislator only stated that the application of weapon to convicts, who are deprived of liberty, is also allowed in other cases that are stipulated by the laws of Ukraine "On the National police" and "On the National guard of Ukraine" (the part 6 of the article 106 of the Code), which, according to the requirements of the criminal executive legislation of Ukraine (of the Criminal executive code; of the Law of Ukraine "On the State criminal executive service of Ukraine"; of the Law of Ukraine "On the Pre-trial Prison", etc.), has no bearing to the protection of the PEI and the supervision for the convicts that are deprived of liberty, except in cases, which are specified in the art. 105 of the Criminal executive code.

So, today, it's worth acknowledging that the procedure of the application of the weapon to convicts, who are held in the educational and correctional colonies of Ukraine, not only does not conform to the Constitution of Ukraine (in particular, article 92), but also to the norms of international law (such as: the part 1, of the article 6 of the International covenant on civil and political rights).

On this basis, the Criminal executive code of Ukraine should be supplemented by the art. 106-1 "The grounds and procedure of the application of firearms to convicts that are deprived of liberty" taking as a basis the provisions of the articles 43.46 of the Law of Ukraine "On the National police", namely:

1. The firearm is applied to convicts that are deprived of liberty in exceptional cases, when another predicted measures of the influence on the personality of the offender failed to produce the desired result.

2. The personnel of the colonies are able to apply the firearm in the following causes:

\footnotetext{
8 Про затвердження Виправно-трудового кодексу Української РСР : затверджений Законом Української РСР від 23 грудня 1970 р. № 3325-07. Відомості Верховної Ради Украӥнської РСР. 1971. № 1. Ст. 6.
} 
1) for the reflection an attack on a person of the personnel of the colony in the event of a real threat to his or her life or health;

2) for the protection of other persons, who are in the protected territory of the colony from the attack that endanger their life or health;

3) for the exemption of the hostages, who are held in the protected territory of the colony;

4) for the reflection of the attack on convoys and protected objects of colonies and the exemption them in the event of capture;

5) for the apprehending a person that was caught in a committing the serious or particularly serious crime and who tried attempting to flee;

6) for the detention of the convict, who offers armed resistance and tries to escape from custody, as well as the weaned convict, who threatens by the application of weapon and other subjects that endanger their life or health of the persons from the number of the personnel of the colonies and other persons;

7) for the stopping the vehicle by the way of the damaging it, if the convict uses it for the committing the unlawful actions and creates in such a way the endanger the life or health of the persons from the number of the personnel of the colonies and other persons.

3. Before the using firearms, the personnel of the colony is obliged to warn the convict in advance of the use and to give him sufficient time to fulfill the legitimate requirement of the person of the personnel, except the causes when a delay can cause the endanger the life or health of another person or the personnel of colony, or other grave consequences, or in the established situation, such a warning is either unjustified or impossible.

4. The warning about the application of a firearm may be the voice of a person of the personnel of the colony, but at a considerable distance to the offender or to a large group of convicts - through loudspeakers or sound amplifiers.

5. The person of the personnel of the colony who has used a firearm has the right to cause such harm to the offender, which is necessary and sufficient in such an environment.

6. In the case of injury of a convict, the person from the personnel of colony who applied firearm, is obliged to provide him with urgent medical care and to inform immediately about this case the management of the specified punishment execution institutions, as well as to apply another actions, that specified in the law.

The analogical grounds for the application of firearms are enshrined in the art. 18 of the Law of Ukraine "On the National guard of Ukraine". 
Thus, it must be acknowledged that, for both police officers and servicemen of the National Guard of Ukraine, the legislator has created the proper conditions and legal guarantees for the application of firearms in correctional and educational colonies in cases, about which is told in the part 6 of the 106 of the Criminal executive code of Ukraine.

At the same time, the activity of the personnel of the colonies on the specified issues are still not regulated at the law level, which is not only contrary to the requirements of international legal acts, but also to the Constitution of Ukraine (the part 2 of the article 19 and the paragraph 14 of the part 1 of the article 92), and therefore, solving this problem is an urgent task today.

\section{International practice the right of convicts for the personal safety}

Interesting in this regard is the such practice in Switzerland prisons, namely: the personnel of this correctional institutions are not provided by the measures of the protection, which are applied in the time of the active resistance of convicts in other countries.

The only type of special means that is used by the personnel of the prisons in this country is the handcuff, but its application is possible only then, when the convict wants to harm himself.

However, about the rubber truncheons or weapon (including gas) are not discussed at all.

Moreover, in Switzerland there are no penitentiary paramilitary units and specialized units, who have the right to use forceful methods of influence on the convicts 9 .

Of course, this approach is not indisputable, especially given the quantitative and qualitative characteristics of the convicts, which are held in the correctional and educational colonies of Ukraine, however, the fact is obvious that the carrying of special measures and weapons by personnel of this PEI does not contribute to the establishing a trusting and sincere relationship with individuals that are deprived of liberty, as well as is the circumstance that provokes (encourages, seduces, etc.) the latter to its application in cases where it is unnecessary and inappropriate in the relationship between the convict or the group of them.

The art. 7 of the of the International the covenant on civil and political rights, in which it is specified that no one shall be subjected to torture or cruel, inhuman or degrading treatment or punishment.

\footnotetext{
9 Сахнік О.В. Практична та гуманістична спрямованість професійної підготовки пенітенціарного персоналу зарубіжних країн. Зарубіжний досвід функиіонування пенітенціарних систем: сторінки історії та виклики сьогодення : матеріали круглого столу (Київ, 14 травня 2015 р.) / відп. ред. О.В. Сокальська. Київ : Ін-т крим.-викон. служби, 2015. С. 84.
} 
These provisions are reflected in the art. 28 of the Constitution of Ukraine and in the part 1 of the art. 8 of the CEC, in which it is discussed the right of the convicts for the humane treatment and for the respect for their human dignity, as well as about that these persons shall not be subjected to torture or cruel, inhuman or degrading treatment.

All this serves as an additional argument regarding the modification of those norms of the criminal executive legislation of Ukraine, which is related to the issues of the application to the convicts that are deprived of liberty, of the measures of the physical influence, special means and weapon.

The part 1 of the art. 9 of the Covenant, in which it is established that every person has the right to liberty and security of person.

A similar provision is enshrined in the part 1 of the art. 29 of the Constitution of Ukraine and in the part 1 of the art. 8 of the CEC of Ukraine, in which it is specified that the measures of influence may be applied to the convicts solely on the basis of the law, which also confirms the conclusion that it is necessary to supplement this Code with a separate norm on the grounds and the procedure for applying firearms to convicts that are deprive of the liberty.

Therefore, in this regard, we can find another way.

Thus, in the art 256 of the CEC of the Republic of Poland it is discussed that the application of the measures of direct coercion, weapon or service dogs to persons that are deprived of liberty, are regulated by the law ${ }^{10}$.

The part 1 of the art. 10 of the Covenant, in which it is determined that all persons that deprived of the liberty have the right for humane treatment and respect for the dignity, which is inherent in the human personality.

The same provision is enshrined in the part 1 of the art. 28 of the Constitution and in the part 1 of the art. 8 of the CEC (in the form of the rights of the convicts to their humane treatment to them and respect for their dignity), as well as in the art. 5 of the specified Code (in the form of the principle of humanism - as of one of the principles of the criminal executive legislation, the execution and the serving sentences).

Given the specified, the art. 106 of the CEC it would be logical to supplement by the part 8 of the following content:

"In the application to convicts that deprived of the liberty, of measures of the physical influence, special means and weapon, the personnel of the colonies and others that are involved in the procedure that is

\footnotetext{
10 Роль і вплив кримінального та кримінально-виконавчого законодавства Польщі у реформування правового поля України : Методичні рекомендації зі спецкурсу «Основи реформування кримінально-виконавчого законодавства України» / О.Г. Колб, А.Б. Косило, О.М. Юхим’юк, А.М. Октисюк. Луцьк : «Вежа», 2011. С. 74.
} 
determined in the part 6 of the current Code, the persons should provide the right for the humane treatment to them and respect for their dignity".

This approach builds on the existing practices of the activity of the personnel of the colonies on these issues, as well as on the decisions of the European Court of the rights of human.

In particular, the judgment of 15 May 2012 in the case "Kaverzin against Ukraine", the specified Court has determined about the violation of the art. 3 of the Convention on the protection of the rights of human and fundamental freedoms in connection with the torture of the applicant and the application of handcuffs in the colony ${ }^{11}$.

Moreover, the ECHR that is based on the art. 46 of the Convention, immediately obliged Ukraine to implement the reforms that are aimed at eradicating the practice of ill-treatment with convicts.

\section{CONCLUSIONS}

If to compare the specified norms of the Rules with the provisions of the current criminal executive legislation of Ukraine on issues of the application of the measures of physical influence, special means and weapon to convicts that deprived of liberty, than we are able to make the following conclusions:

1. In the Minimum standard rules for the treatment of convicts, as in the normative legal acts of the general direction, the principle of exclusivity is enshrined, which is which is a priority in the application to persons that are held in the places of deprivation of liberty (isolation) of restraint measures that are defined in the law.

In addition, this, in turn, is an additional argument regarding the addition of the part 1 of the art. 106 of the CPC of Ukraine, namely - "the principle of the exclusivity" in the actions of the personnel, which are caused by the unlawful behavior of the convicts.

2. Unlike the CEC and other laws of Ukraine ("On the National police" and "On the National guard of Ukraine"), in the Rules this procedure of the application of the restraint measures is defined by the central prison administration, which, in the view of the requirements of the Constitution of Ukraine (the part 2 of the article 19 and the paragraph 14 of the part 1 of the article 92), is inadmissible, whereas the granting of the right to such activity is based on the ground of the by-law normative legal acts, as well as defining the grounds and the procedure of the application of the measures

\footnotetext{
11 Каверзін проти України : рішення Європейського суду з прав людини від 15 травня 2012 р. Практика Європейського суду з прав людини. Рішення. Коментарі. Київ : Міністерство юстиції України, 2013. № 2. С. 15.
} 
of the physical influence, special means and weapon by the departmental legal sources, as the history of the places of the deprivation of liberty shows, leads to arbitrariness, torture and other inhumane treatment of convicts.

Unfortunately, the issue of "the departmental approaches" in Ukraine, especially in the area of the punishments, is still relevant in the current time.

3. The legal grounds of the carrying weapons by the personnel of the correctional facilities in the Rules are formulated sufficiently blurred, unclear and haphazard, and it is not discussed about its application.

Therefore, speaking about the standards of the treatment of convicts from the specified areas of activity of the personnel of the PEI that are enshrined in the current Rights, it can only be conditional and only in that part, which is able to be used in Ukraine for the development of the legal foundations of the application of the measures of the physical influence, special means and weapon to such persons.

\section{SUMMARY}

In the provisions of the scientific article the author research a scientific problem adaptation of convicts' legal status to European standards. This problem is especially urgent for the sphere of punishment execution exactly in Ukraine, as in all civilized states it is established at the legislative level, that a convict enjoys all rights of a person and a citizen, with the exception of restrictions, determined by law and established by court verdict. Moreover, being a member of United Nations Organization, European Council or other authoritative international organizations, each state member undertook juridical obligations to bring national legislation to generally recognized principles and norms. The scientific article examines international legal acts, and the experience of European countries Switzerland and Republic of Poland, norms of national legislation of Ukraine, on issues adaptation of convicts' legal status to European standards.

\section{REFERENCES}

1. Статут Ради Свропи від 5 травня 1949 р. Офіційний вісник Украӥни. 2004. № 26. Ст. 17.

2. Конституція України. Київ : Алерта, 2019. 81 с.

3. Загальна декларація прав людини. Збірник міжнародно-правових актів та угод з питань діяльності пенітенціарних установ і поводження з в'язнями. Київ : Вид-во «АННА-Т», 2008. С. 13-17.

4. Сванидзе Э. Эффективные расследования жестокого обращения. Руководящие принципы по применению европейских стандартов. Киев : Изд-во «ВПК Экспресс-полиграф», 2011. 150 с. 
5. Мардох Д. Боротьба 3 жорстоким поводженням і безкарністю та ефективне розслідування жорстокого поводження. Доповідь по Україні. Київ : «К.І.С.», 2010. 108 с.

6. Михалко I.C. Галузевий принцип раціонального застосування примусових заходів і стимулювання поведінки засуджених як підгрунтя ефективності дії основних засобів виправлення і ресоціалізація засуджених. Засоби виправлення $i$ ресоціалізаиії засуджених до позбавлення волі: монографія / за заг. ред. Степанюка А.Х. Херсон : Кроссроуд, 2011. С. 275-298.

7. Міжнародний пакт про громадянські та політичні права : прийнятий 16 грудня 1966 р. Генеральною Асамблеєю ООН (резолюція № 2200 A (KНКНI). Збірник міжнародно-правових актів та угод з питань діяльності пенітениіарних установ і поводження з в'язнями. Київ : Вид-во «AHHA-T», 2008. С. 27-45.

8. Про затвердження Виправно-трудового кодексу Української РСР : затверджений Законом Української РСР від 23 грудня 1970 р. № 3325-07. Відомості Верховної Ради Украӥнської РСР. 1971. № 1. Ст. 6.

9. Сахнік О.В. Практична та гуманістична спрямованість професійної підготовки пенітенціарного персоналу зарубіжних країн. Зарубіжниий досвід функиіонування пенітенціарних систем: сторінки історії та виклики сьогодення : матеріали круглого столу (Київ, 14 травня 2015 р.) / відп. ред. О.В. Сокальська. Київ : Ін-т крим.-викон. служби, 2015. С. 82-85.

10. Роль i вплив кримінального та кримінально-виконавчого законодавства Польщі у реформування правового поля України : Методичні рекомендації зі спецкурсу «Основи реформування кримінально-виконавчого законодавства України» / О.Г. Колб, А.Б. Косило, О.М. Юхим’юк, А.М. Октисюк. Луцьк : «Вежа». 2011. 84 с.

11. Каверзін проти України : рішення Європейського суду з прав людини від 15 травня 2012 р. Практика Європейського суду з прав людини. Рішення. Коментарі. Київ : Міністерство юстиції України, 2013. № 2. С. 15-60.

\section{Information about author:}

Batiuk O. V.,

ORCID ID: 0000-0002-2291-4247

Candidate of Law Science, Associate Professor, Professor of the Chair of Criminal Law, Process, Criminalistics Kyiv Institute of Intellectual Property and Law National University "Odessa Law Academy" 210, Kharkiv highway, Kyiv, Ukraine 